\section{Jean Célestin Ky}

Jean Célestin Ky studied at the University of Paris I, Pantheon-Sorbonne, and is Senior Lecturer in Art History at the University of Ouagadougou, Ouagadougou, Burkina Faso. E-mail: kycelestn@yahoo.fr; jean_ky@univ-ouaga.bf

\section{The visual arts at the biennial Burkinabè National Cultural Week}

\title{
The visual arts at the biennial Burkinabè National Cultural Week
}

Every two years the Ministry of Arts, Culture, and Tourism of Burkina Faso organises a National Cultural Week in Bobo Dioulasso. Its main objectives are to develop and promote Burkinabè culture and artists. This event, which includes numerous domains of art, nevertheless remains quite obviously a framework for the development and promotion of the performing arts in particular. The visual or fine arts do not seem to have found in this event the means of expression whereby their development can best be promoted. The constraining factors for this category of art are the confusion that exists between traditional and contemporary art, the anonymity of visual artists, the absence of a theme around which the competition can be organised and the unfortunate fate reserved for prize-winning art works and artists. Proposals for solutions are made here in the hope that these will enable the National Cultural Week to become the springboard for the development of the visual arts. Key words: Burkinabè National Cultural Week, Burkinabè visual arts, Burkinabè fine arts, Burkinabè visual art promotion, artistic development in Burkina Faso.

In Burkina Faso, the Semaine Nationale de la Culture (SNC, National Cultural Week) takes place every two years in Bobo Dioulasso, the second most important city in the country. It is a cultural event and the competition it hosts brings together innumerable artists in fields such as the performing arts, the art of cooking, traditional sport and social games, literature and visual arts, et cetera.

From the time of its establishment until today, the SNC has recorded the participation of visual arts and artists. But this cultural event, in the way it is organised and experienced by the artists, accords importance and notable privileges to certain artistic expressions. This state of affairs evokes questions about visual arts, but these could be extended to include other domains of art. Thus, twenty years after the first SNC Week, one could ask the following questions:

- Has the SNC furthered expression in the visual or fine arts?

- Has it promoted visual artists?

- What place is accorded to the visual arts and artists during this week? 
The organisation of the SNC is a very recent facet of cultural life in Burkina Faso. The main sources of material for examining it are the founding texts of the event; the reports of previous SNCs; general reports on seminars on the SNC; rare works (dissertations) on this cultural event; personal observations of witnesses and some artists.

The results of my reflections presented here are divided into two distinct parts. The first part, that of general aspects, concerns the creation of the institution, the desired aims and the organisation of the events. It is not really an analysis of the subject, but rather a review that serves to introduce the second part. The second part concentrates on the visual or fine arts and describes their share in past SNCs, from the preliminary to the final phases. It identifies the obstacles and constraints that prevent more visual artists from taking part. At the same time, in order to stimulate the visual arts at the SNC, some solutions to the problems are put forward.

\section{Semaine Nationale de la Culture: general aspects}

In Burkina Faso, the 1980s witnessed the first attempts of cultural reform. One of these was the SNC, established by the Conseil du Salut du Peuple (CSP, Council for the Salvation of the People) in July 1983 and put into practice by the Conseil National de la Révolution (CNR, National Council for the Revolution) in December 1983. ${ }^{1}$ The first texts creating the SNC are Decree No 329/ENAC/DGAC and Decision No 325/ENAC/ DGAC of 29 July 1983 of the Minister of National Education, Arts and Culture (TraoréSanogo 1996: 24). This was an initiative of the Conseil du Salut du Peuple that proposed the event, the Grand Prix National des Arts et des Lettres National (GPNAL, the Grand Award for Arts and Literature) and other cultural events. But, overthrown a few days later, the CSP was denied the opportunity of organising this cultural event. The Conseil National de la Révolution that succeeded the CSP organised the first SNC in Ouagadougou from 20 to 30 December 1983.

The Revolution inspired the text that created and set up the SNC in accordance with the cultural vision expressed in the Discours d'Orientation Politique (DOP, the Speech of Political Orientation) on 2 October 1983, i.e. a wide-ranging speech on national radio and television by President Thomas Sankara setting out the political programme of the CNR. The SNC was envisaged as a project affirming Burkinabè cultural identity. Decree No 84-250/CNR/PRES of 27 June1984 decreed that the SNC would be an annual event. This is why the second SNC took place in Gaoua in 1984. But after these events, problems of cultural infrastructures, as well as problems regarding infrastructures for reception and accommodation, led the authorities to revise the frequency of the SNC. This necessitated a third text, Decree No 85-486/CNR/ PRES/MIC of 29 August 1985 making the SNC a biennial event, thus giving the host provinces two years to prepare, the time needed to provide cultural infrastructure 
and accommodation. It was in accordance with this decision that the SNC Bobo' 86 and the SNC Koudougou-Réo' 88 were held.

The year 1990 was a very important turning point for the SNC. On 15 October 1987, a military coup d'état, which led to the death of President Sankara and his supporters, established Le Front Populaire (FP, the Popular Front) and committed the country to a movement known as Rectification (sic) Captain Blaise Compaoré, who acceded to power to that end led an emergency regime until 1991. During this period important decisions relating to the cultural biennial were taken: the SNC was settled in BoboDioulasso, henceforth the only town to accommodate the event; it is administered by a permanent secretariat based in that city. Order No 91-37/MIC/MDC/SP-SNC of 25 July 1991 laid down the powers, organisation and running of the full structure of the SNC and every event is governed by a Ministerial Order according it legitimacy. ${ }^{2}$ These measures have entrenched the SNC, making it the unrivalled and biggest national cultural event in Burkina Faso. However, from 1990 to the present, seminars reflecting on the SNC have been held with a view to identifying its achievements, in order to conserve or consolidate them, and its inadequacies, in order to correct these. ${ }^{3}$

\section{Objectives and organisation}

Research has shown that Burkina Faso comprises about sixty ethnic groups, each of which often has its own cultural expressions. To identify and understand the objectives assigned to the SNC, it is advisable to do a historical review. The present state of knowledge allows one to define three main phases in the history of the colonisation of Burkina (Kouanda 1986: 50): colonisation prior to the 15th century, which is that of the Bobo, Bwa, San, Yônyôosé, Nînsi, Gurunsi, Dogon, Kurumba and the Bisanô (sing. Bisa); colonisation between the 15th and 17th centuries, which is that of the Moose, Gulmanceba, Fulbé, Yarsé, Marka, Zara; and colonisation at the end of the 17th century, which is that of the Lobi, Dagara, Hausa, Dyula. As a result of these three waves of immigration, the population has been divided into two groups: autochthons or populations previously settled (a group comprising those settled before the 15th century) and people coming from elsewhere (a group composed of populations settled from the 15th century onwards).

The conquest of the territories of Burkina Faso, begun in 1896 ended before 1900. But Burkina Faso would only become a colony in 1919. That lasted until 1932, when it was dissolved for various reasons. In 1947 the colony of Upper Volta was reconstituted within the 1932 boundaries. It became part of the French Community by voting "yes" in the referendum of 28 September 1958. On 11 December 1958 it became a Republic before gaining its independence on 5 August 1960. From 1900 to 1960, which corresponds to the colonial period when the territories of Burkina Faso were under French supervision, there was a campaign to negate local cultural practices in favour 
of those of the coloniser. Thus, the pre-colonial period of cultural dynamism and remarkable sentiments of cultural pride was followed by a period in which cultural values were called into question. French civilisation, disseminated by schools and Christianity, destabilised various domains of Burkinabè culture. It is in the context of the denial of the foundations of Burkinabè culture that the independence of 5 August 1960 was proclaimed.

What steps did the State take to rehabilitate Burkinabè culture? From 1960 to 1983, while the promotion of culture remained a preoccupation for the different authorities that succeeded one another, none of them displayed the political will to make culture an essential human dimension and the basis for development. The absence, until fairly recently, of an autonomous Department of Culture did not help to promote this standpoint. Cultural policies were restricted to a few actions, among which can be mentioned the creation of a National Museum, the birth of cinematography and the establishment of a Directorate of Cultural Heritage. The National Museum was established by Act No 42/62/AN of 13 November 1962 (Traoré 1985/1986: 18) and entrusted with the mission of creating a space to safeguard and preserve the collective memory of the Burkinabè nation. It was already in 1962 that a cinema unit attached to the General Directorate of Information was created (Traoré-Sanogo 1996: 21). Its mission was to produce socio-educational, didactic films and newsreels for the rural population in particular. ${ }^{4}$ It was only in 1972, ten years after the National Museum came into being, that the Directorate of Arts, Literature and Cultural Heritage was formed (Yaméogo 1989), under the administrative supervision of the Department of National Education.

In actual fact, the lack of independence that long characterised the management of culture in Burkina Faso did not favour the early evolution of a true cultural policy or the birth of a vision for this subject matter. Culture, at first completely absent from the organisational charts of government (1960-1971), then supervised for a while by the Department of National Education, later attached to the Department of Youth and Sports (from 1971 to 1983 probably), would be better served by private initiatives than by any specific government led policy. This is why in 1983, apart from cinematography where notable efforts had been made, other cultural fields were largely neglected. Indeed, the performing arts, visual arts, literature and local crafts, despite being the essential domains of Burkinabè culture, were promoted poorly or not all. This was the state of cultural affairs when the change in government took place in 1983.

The government put into power by the military coup d'état of 4 August 1983 recognised the importance of culture in the transformation of Burkina Faso. ${ }^{5}$ This culture, which has a national character, should be the source of all cultural expressions and every aspect of the cultural heritage. The renewal of culture is intended to create a cultural identity indispensable for the awareness of self-worth and self-confidence. Not many would deny that, from 1983 to the present, the political will to restore Burkinabè culture and affirm the Burkinabè nation in their culture has grown 
ever stronger. This process will not be analysed here, my aim being rather to identify the objectives that founded the SNC.

As we have seen, the SNC was an initiative of the CSP that the CNR brought into being by organising the first National Culture Week four months after its accession to power, from 20 to 30 December 1984. This event has managed ever since to overcome the various trials it has encountered and it still takes place. Indeed, if one skims through the founding texts of the SNC and the various reports and seminars of this institution, one finds that the objectives assigned to it have remained the same. They can be summarised as follows: the revitalisation of the cultural life of the nation; the reassertion and rediscovery of the national cultural and artistic heritage; the affirmation of a cultural identity; the cross-fertilisation of different cultural identities and the promotion of artists. According to the texts, the SNC is clearly the context that favours the expression of all spheres of art in Burkinabè culture and promotes the best artists.

How is this biennial event organised? In the organisational process of the SNC, the eliminatory contests that constitute the preliminary phase are held in stages. First of all, every district [département] has the opportunity to organise cultural days. ${ }^{6}$ The competition at this level concerns the villages that make up the district, allowing the best artistic ensembles and the best works of art to be chosen. Next, provincial cultural days are held in which the troupes and objets d'art of the different districts of the province in question compete with one another. After the provincial days, every province chooses its best troupes and objets d'art for the regional level of the competition. The regional culture weekis held by ministerial order and organised by a host province with the technical and financial support of the permanent secretariat of the SNC. At this stage, the national juries, nominated by the secretariat, choose for every region the best artistic ensembles, works of art and dishes cooked presented by the provinces.

These different selections result in the final phase: the huge cultural event held in Bobo Dioulasso for one week. The final stage, the showcase of Burkinabè culture, comprises a competition section and a festival section. In the context of the competition, performing artists, visual artists, writers, filmmakers and many others compete for the ultimate prize called the Grand Prix National des Arts et des Lettres. Competitions in culinary art and in traditional sports are not considered for this award. ${ }^{7}$ These final competitions enable the best artists and writers of Burkina Faso to be named at the closure. As for the festival section, it displays various aspects of culture that are not part of the competition. These events include parades and dances of masks, equestrian exhibitions, fashion shows, the fair, ${ }^{8}$ exhibitions of museum art, ${ }^{9}$ entertainment and leisure activities such as the "village of communities," ${ }^{10}$ spaces for children (training activities, game contests), spectacles and social dances, tourist activities, colloquia, seminars and lectures.

All these activities and events contribute to the excitement of the SNC and make it a real celebration experienced by all those that attend the festival and by others who 
watch live broadcasts by national television of the GPNAL competitions for performing arts and commentary on certain spectacles. Let us now turn our attention to the place occupied by visual arts in the competition section of the SNC.

\section{The visual arts (1983-2004)}

The aim of this part of my article is to uncover and reveal the involvement of visual arts in the various SNCs, with a view to identifying any shortcomings and obstacles that prevent the true promotion of this domain of art. The participation of the visual arts in this event includes the exhibitions of artists at the fair for commercial purposes, exhibitions of museum art and the GPNAL competition. It is the latter, the competition in visual arts, that is in debate here and that forms the subject of the present reflection.

\section{The visual arts competition}

In the GPNAL competitions of the SNC, visual arts fall under category B. ${ }^{11}$ Visual arts are those arts that produce or reproduce forms or mass; they belong to the art of representing forms. According to the traditional classification, the visual arts include architecture, sculpture and painting. However, in Burkina Faso, the concept of visual arts is much wider. Reality has led to certain practices being added, notably techniques that produce objets d'art. Thus from 1983 the following disciplines were included under visual arts: sculpture, painting, bronze work, batik, photography, leather craft, weaving, fashion, hairdressing, drawing, pottery and basketwork.

For the purposes of the competition, these domains remained registered under visual arts until the 1996 SNC. Then, for the GPNAL of the 1998 SNC, a ministerial order concerning regulation category $\mathrm{B}$ retained as visual arts only the domains of sculpture, painting, batik, bronze and drawing for children, the latter domain disappearing later ${ }^{12}$ (see Order No 99-0011/MCC/SG/SP-SNC, Order No 2003-395/MCAT/ SG/SP-SNC and Order No 2005-201/MCAT/SG/SP-SNC). As soon as the internal regulations are published, the artists register for the eliminatory rounds of the disciplines belonging to their specialities. It seems, however, that the eliminatory rounds at the levels of departments and provinces often do not take place for the visual arts. This impression is based on a testimony and on personal experience. Indeed, in October 1997, when the regional selections were made at Dédougou, a cultural assistant of the province of Nayala advised me that the entries from this province had not undergone selection before being presented at regional level. Moreover, in my capacity as member of the jury for regional selections, I have observed certain artists presenting their works themselves, instead of this being done by the cultural officials of their

provinces. This means that the first level of the competition in visual arts begins in actual fact at the level of the cultural region. 
The first regional selections began with the $2^{\text {nd }}$ SNC (Traoré-Sanogo 1996: 52). Until the regional selections for the 2004 SNC, which took place in 2003, Burkina Faso was divided into five cultural regions, each consisting of several provinces, to which were added the autonomous regions of Houet and Kadiogo as well as the diaspora in Côte d'Ivoire. But, from 2004, Burkina Faso has been divided into fourteen cultural regions. In fact, regional selections in visual arts have undergone a modification that does not seem to have been to their benefit. Whereas, until 1999, every region used to receive the selection jury, from 2001 onwards the regions for visual arts have been restricted to the autonomous provinces of Houet and Kadiogo. This means that selection of the works in category B is carried out in two zones, one in the province of Houet and the other in the province of Kadiogo, the works being shared out between these two zones. There, the first three works, provided they obtain an average of at least $13 / 20$ in each of the disciplines, are sent through for the final phase. ${ }^{13}$ Calculation shows that a maximum of 84 objects has been reduced to a maximum of 24 for the final phase of the competition.

The works of art are received by the Permanent Secretariat of the SNC and handed over to the Exhibition Committee. This committee exhibits them in a hall, attributing to every object a code to ensure anonymity. According to testimonies received, when visual arts included sculpture, painting, bronze work, batik, photography, leather craft, weaving, fashion, hairdressing, drawing, pottery and basketwork, with seven regional selections, about a hundred works would be sent through to the final phase and would require examination. But, when the disciplines of visual arts were restricted to sculpture, painting, bronze work and batik, only about fifty works reached this stage of the competition (see Report on the Deliberations of the Jury for Category B of the GPNAL of the 10th SNC). And the limitation of cultural regions to 2 for this category has once again reduced the number of objects in the final phase; the last SNC only recorded 25 objects (see Report on the Deliberations of the Jury for Category B for the 2004 SNC at Bobo).

It is in the final phase that the best objects are chosen and awarded prizes. This task is given to a jury nominated by order of the Minister responsible for culture, based on the proposals of the Permanent Secretariat of the SNC. The national jury is composed of five members who are autonomous and whose judgement is final. Before beginning their work, the members of the jury define and synchronise the criteria of appraisal and the marks to be attributed to the various criteria. ${ }^{14}$ The following criteria are regularly used: originality, creativity, aesthetics, composition, execution, finish and pertinence to the theme. Every member of the jury gives marks to the works, which are still anonymous, based on the criteria selected. The average of the marks awarded to every object determines its overall position. The jury only reveals the identity of the artists when they are ranked according to the averages obtained. The official prize list only mentions the first three works in every discipline and then 
only provided they have obtained an average of at least 13/20. These are also the only works that are awarded prizes. They automatically become part of the national Burkinabè heritage through their acquisition by the State. What analysis can be made of the visual arts competition at the SNC?

\section{Analysis of the participation of the visual arts in the National Cultural Week}

It must be remembered that the basic purpose of the SNC is to highlight all aspects of Burkinabè culture and to promote the artists. As far as visual arts are concerned, one is obliged to state that the SNC has failed to develop all the spheres of this discipline, nor has it promoted the artists concerned; the progressive decrease in the number of participating artists confirms this opinion. Even a casual survey of the competition of this category at the SNC reveals inadequacies, which explain, although they do not justify, the lack of interest or decline in visual arts.

The SNC does not distinguish between traditional art and contemporary art in category B, whereas in the performing arts the domains of traditional dance, traditional music and traditional singing are recognised. In actual fact, contemporary art uses modern materials, tools and techniques; in contrast to this, there is traditional art with all the elements that characterise it. In my opinion it is injudicious to apply the same criteria to assess the value of these two very different kinds of art. The absence of a section for traditional visual arts places the artists who work according to the traditional cultural canons at an unfair disadvantage. Because the criteria of judgement favour contemporary art forms, the prizewinners are always those artists who work in studios in urban areas and who have received formal training. Rural artists have come to realise that category B of the competition is not intended for them.

This kind of exclusion of traditional artists hinders the promotion of visual arts with regard to Burkinabè culture. Indeed, in Burkina Faso as elsewhere in Africa, traditional works of art serve as a vehicle for the history of the groups that, in order to materialise the forms, safeguard their cultural norms. This is the reason why different artistic possibilities exist to represent the same images. Thus the Moose, Nuna, Léla, Bwa, Bobo, Winiéma, Marka, Kurumba and other ethnic groups each have their own conventions for depicting antelope or buffalo, for example. To preserve and develop all the traditional resources of the visual arts, competitions must be organised differently. Category B of the SNC competition must be divided into two sections, these being traditional art and contemporary art. Traditional art includes sculpture (wood, bronze), leather craft, weaving, fashion, hairdressing, pottery, basketwork and painting (Pibot 2001). Contemporary art incorporates sculpture (wood, bronze, stone and iron), batik, design, composite arts, and painting (Kaboré 1992/1993; Eliard 2002).

In addition to the absence of traditional cultural canons, visual artists suffer the drawback of anonymity; at no stage of the SNC is the visual artist afforded the opportunity of making her/himself known. Visitors to the exhibition who like a work of art 
and want to enter into contact with the artist cannot do so because of this anonymity. The obligation to remain anonymous also prevents any encounter with foreign artists or organisers of symposiums or international exhibitions sales. Thus, at the end of the SNC, the visual artist returns home without any contact that could open up new horizons. In contrast to this, performing artists benefit from the SNC by meeting especially foreign promoters, which often leads to invitations to perform abroad (Traoré-Sanogo 1996: 74-77). To lift the anonymity and better present the visual artist to the public, the final phase of the SNC must be organised differently. The creation of a site for the visual arts, where the artists taking part in the competition could be seen at work, should be envisaged. This could be a lively place in which the artists and their works, those in production as well as those already completed, could be appreciated.

But the absence of a specific theme on which the artists can base their work complicates the task of selection. In fact, the art works of the SNC, even those of the same discipline, all deal with different themes, making it difficult to award marks. Faced with paintings dealing with various themes, an adjudicator could, regardless of the technical quality of the work, be attracted by a theme that is of personal interest. The risk of this happening means that the works are not all on the same level when it comes to assessment, making their chances of being mentioned in the official prize list unfair. To avoid this, it would be advisable to choose a single theme for every SNC on which the artists could base their works..$^{15}$ This theme would be the first criterion by which the works in the competition were judged.

The question of the future of the prize-winning works is also important. The official texts, despite their clarity on this aspect, are not applied. It seems that, in the beginning, although this has not been verified, all the prize-winning works became the property of the State through their acquisition by the National Museum. Thus the first prize-winners had the satisfaction of seeing their productions preserved in the National Museum. Subsequently, this provision evolved to mean that the prize-winning works are bought by the State for the National Museum or rather that the works placed first in every discipline are automatically bought by the Minister responsible for culture for the cultural heritage of the National Museum (Order No 99-0011/MCC) SG/SP-SNC, concerning the Internal Regulation for the National Grand Prize for Arts and Literature, 10th National Cultural Week SNC BOBO 2000). ${ }^{16}$ The works often not acquired by the State are left in the hands of their owners and return to the provinces they came from or are sold on the spot to other buyers.

The works that go to the National Museum do not enjoy an enviable fate. Badly preserved and not displayed to advantage, these objects cannot make their creators known. In fact, recent research has established that no storerooms for the reserve collection exist, nor are any methods, means or techniques of preservation applied in the National Museum, thus placing the life of these objects in danger (Bayala 2004/2005). In contrast, the prize-winning items of the performing arts as well as the prize-winning 
literary works enjoy a far better fate. Subject to control, music cassettes are produced for the best artistic musical ensembles; the latter are also the ones who participate periodically in the "Sahel Caravan" organised by the Minister of Culture, Arts and Tourism. ${ }^{17}$ As for literature, the GPNAL prizes awarded at every SNC to the best literary works represent an opportunity for publication. The list of works published in this context by the Minister responsible for culture is already considerable (TraoréSanogo 1996: 65).

As for the productions of the visual arts, their future is expressed in terms of preservation and display. These objects need better preservation, to protect them from any damage, and better exposure. The best environment for the protection and preservation of an object of artistic, cultural or historic interest is the museum. As the Permanent Secretariat of the SNC does not have one, the National Museum, subject to the improvement of their storage conditions, can continue to receive the best objects awarded the GPNAL prizes at the various SNCs. Their exposure will have to be served by permanent or temporary exhibitions (in the National Museum or at the $\mathrm{SNC}$ ) as well as itinerant exhibitions, especially when the regional selections take place and abroad with the "Sahel Caravan", to display them to the public and at the same time make the artists known. In fact, to improve their exposure, various uses can be found for the best works of art of the SNC, such as decoration and adornment of administrative buildings, motifs printed on loincloths and T-shirts, particularly those for the SNC, designs for postage stamps, etc.

The absence of any promotion of the artists awarded prizes for visual arts must be noted. It seems that, apart for the prizes handed out, these artists receive no favours. During the Revolution, between 1983 and 1987, the State gave tangible expression to their desire for reform in favour of the prize-winning artists, who benefited from considerable orders from the government. For instance, the painter Raya Benjamin Sawadogo, prizewinner of the first SNC, was commissioned to decorate the central market of Ouagadougou and the sculptor who also works in bronze, Ali Nikiéma, prizewinner in 1983, 1984 and 1988, received commissions for the Faso coat of arms in 1984, for the monument commemorating the Battle of the Rail in Ouagadougou in 1986 and the monument to the youth at Ziniaré in 1987 (Traoré-Sanogo 1996: 70-73). This method of promoting the prize-winning artists, despite its interest, has not been continued. It might be a good idea to reintroduce this way of recognising a quality or a work well done, so that the present prizewinners in visual arts could decorate the big public and private markets. Moreover, the latter could play a role as instructors in the training centres for visual arts, for instance the National Centre for Art Crafts and the Craft Village of Ouagadougou. 


\section{Conclusion}

This article contains my personal reflections resulting from my involvement in various selection juries at the regional and final phase levels of the SNC. I have gained the firm conviction that, at this biennial event, the same importance is not attached to all the arts. Created to be a framework for the development and promotion of Burkinabè culture, the SNC seems in effect to accord pre-eminence and primacy to certain specific cultural aspects. Thus, in an obvious manner, the performing arts constitute the essence of the SNC. The place they occupy in the three stages of the SNC (before, during and after) confirms this impression.

Visual arts must be numbered among those arts that have not yet found in this event the means of expression whereby their development can best be promoted. The visual artists' lack of interest in the SNC and their reluctance to take part should be noted and the causes of this must be sought and analysed. Factors militating against this category of art are the confusion that reigns between traditional art and contemporary art, the anonymity of the artist, the absence of a theme around which the competition could be organised, the unenviable fate reserved for the works that receive prizes and for the prize-winning artists.

The limitation of culture to the performing arts or the privilege they are accorded does not further nor develop all cultural expressions as was the intention of the theme for the SNC Bobo 1998: Favoriser et valoriser la rencontre des expressions artistiques ("To further and develop the encounter between artistic expressions"). The treatment of the art of cooking, literature and many other arts, like that of the visual arts, merits analysis; analyses on the basis of which proposals can be put forward for solutions, in the hope that they will make the SNC the springboard for the development of all the arts and all Burkinabè culture.

Translated by Jill Daugherty

\section{Notes}

1. 7 November 1982 marked the end of the Comité Militaire de Redressement pour le Progrès National (CMRPN, Military Council of Reform for National Progress) led by Colonel Saye Zerbo since 25 November 1980. Internal crises in the CMRPN, aggravated by social crises, had resulted in power being seized by the Conseil Provisoire du Salut du Peuple (CPSP, Provisional Council for the Salvation of the People) which later became the CSP. The CSP installed Medical Commander Jean-Baptiste Ouédraogo as Head of State, which he remained until 4 August 1983. On 4 August 1983, the Conseil National de la Révolution (CNR, National Council for the Revolution) acceded to power, led by Captain Thomas Sankara, supported by a group of young officers. The CNR, which had revolutionary leanings inspired by Marxism-Leninism, was overthrown on 15 October 1987 following internal strife between President Sankara and Captain Blaise Compaoré, second in command of the regime.

2. Until 1990, the SNC was merely an activity organised according to directives from the department in charge of culture; initially the Direction Générale des Affaires Culturelles (DGAC, General Directorate of Cultural Affairs) then the Direction de la Promotion Culturelle (DPC, Directorate for Cultural Promotion) and finally the Direction des Arts du Spectacle et des Lettres (DASL, Directorate of Performing Arts and Literature). 
3. Thus in 1985 the Matourkou Seminar took place from 22 to 25 April. It helped establish the foundations of a cultural policy that would play a role in creating national awareness of culture. This seminar proposed the revaluation of the cultural heritage, the promotion of artists and people of learning, the creation of a department of culture, etc. From 5 to 10 April 1993, a seminar was held on the theme, La SNC: Quelle stratégie pour l'avenir? (The National Culture Week: What strategy for the future?) After ten years of existence, it was necessary to look back in order to define achievements and envisage a new direction (see Rapport général du séminaire sur la SNC 1993). Experts discussed similar themes in Bobo Dioulasso in 1997 and October 2004.

4. This was the starting point for an entire policy of cinematographic development in Burkina Faso. Today this country has succeeded in establishing itself as the centre for African cinematography. It can be acknowledged, without going into all the details that Burkina Faso has made a success of its policy to create a Burkinabè film industry and organise African cinematography.

5. When the CNR took power on 4 August 1984, it outlined the general direction of its cultural policy by affirming its support for culture and by creating frameworks to enable artists and people of learning to use and develop their talents. In his major policy speech on 2 October 1983, Sankara expressed this in the following terms: "As for culture, it must have a threefold dimension: national, revolutionary and popular. The Democratic and Popular Revolution will create conditions that will favour the burgeoning of a new culture. Our artists will have the freedom to advance boldly. They must seize this opportunity to raise our culture to a world class level."

6. The division of Burkina Faso into cultural regions has evolved from seven regions in the beginning to the present fourteen regions.

7. In 2004, culinary art was an integral part of the GPNAL, but for 2006 this is no longer the case.

8. The fair first emerged in 1986. Since then, it has become an essential activity for the promotion of Burkinabè products. Through the fair, the Burkinabè display their talent or expertise in the domains of visual arts, cooking, handicraft, pharmacopoeia and even industry. The fair also enables them to reach commercial goals in the short and medium term; exhibitors are able to exploit every commercial opportunity to conquer internal and sub-regional markets.

9. In the case of the SNC the museum exhibitions display a portion of the cultural life of our country. The exhibition of Bobo '98 had as its theme "The image of woman in Burkinabè statuary". It provided the opportunity to highlight the role of women in different societies through a varied range of figurines in wood and bronze. At the 2000 biennial, an exhibition on the theme "Traditional musical instruments, function and evolution" exhibited a series of traditional artistic objects, an element of our cultural heritage. These exhibitions make the Burkinabè more aware of their cultural riches, encouraging them to appreciate and develop them.

10. The "village of communities" presents everyday life of these communities as it infolds in the villages. It highlights an art of living in rural communities based on millet beer or bandji (palm wine), music, etc. Popular festivities organised around jesting relationships are a powerful cohesive factor between the various cultural communities. The "village of communities" celebrates solidarity and fosters cultural cross-fertilisation.

11. The GPNALs of the SNC included three categories, these being categories A for the performing arts, B for visual arts and C for literature. The reform of 1997 introduced categories D (speech in the national languages), E or Youth Pool (artistic creations by young people) and F (cinema and audiovisual productions).

12. For the 13th SNC - Bobo 2006 - the ministerial order specified that category B comprised the following disciplines: sculpture, painting, batik and composite arts.

13. The new rules authorise the selection at this level of the competition of the first six works of every discipline.

14. As the "internal regulation" does not specify any criteria whereby the works are to be appraised, it is left to the jury to determine them.

15. This is done for drawing competitions; logo contests or models made according to instructions from sponsors.

16. The "internal regulation" of the SNC Bobo 2006 states that the works in the official prize list are the property of the Burkinabè State. A fixed compensation amounting to $150000 \mathrm{~F}$ CFA will be paid to every prizewinner, this being the purchasing fee for the work (see Order No 2005-201/MCAT/SG/ SP-SNC); $[1$ Euro $=655.957$ F CFA $]$. 
17. The "Sahel Caravan", composed of Burkinabè dance and musical troupes, travels abroad, to neighbouring countries especially, in order to highlight aspects of Burkinabè culture. The "Sahel Caravan" has already visited among other countries Côte d'Ivoire, Mali and Ghana.

\section{Works cited}

Balima, S-A. 1996. Légendes et histoire des peuples du Burkina Faso. Paris: Imprimerie de l'indépendant.

Bayala, E. 2004/2005. La gestion des collections du Musée National et la question de sécurité dans les réserves. Unpublished Mémoire de Maîtrise. Université de Ouagadougou.

Coquery-Vidrovitch, C. (ed.). 1992. L'Afrique occidentale au temps des Français. Colonisateurs et colonisés, c. 1860-1960. Paris: La Découverte.

Eliard, S. 2002, L'art contemporain au Burkina Faso. Paris: L'Harmattan.

Kaboré, E. 1992/1993. La peinture contemporaine au Burkina Faso. Unpublished Mémoire de Maîtrise. Université de Ouagadougou.

Kambou-Ferrand, J.M. 1993. Peuples voltaïques et conquête coloniale, 1885-1914, Burkina Faso. Paris: L'Harmattan.

Kiethega, J.B. 1993. La mise en place des peuples du Burkina Faso. Découverte du Burkina Faso, tome 1. Ouagadougou: Editions Sepia, ADDB, 9-29.

Kouanda, A. 1986. L'historiographie du Burkina: un bilan. Connaissances du Burkina. CERLESHS: $43-54$.

Nikiema, 1. 2004/2005. La SNC, moyen d'affirmation de l'identité culturelle. Unpublished Mémoire de Maîtrise Université de Ouagadougou.

Ouedraogo, D. 1989. Pour une réorganisation des Semaines Nationales de la Culture. African Cultural Institute, Regional Centre for Cultural Action, Cultural Counsellors Section, Project Dossier, Lomé.

Pibot, J. 2001. Les peintures murales des femmes kasséna du Burkina Faso. Paris: L'Harmattan.

Sankara, T. 1983. Discours d'Orientation Politique (DOP). Prononcé le 2 octobre 1983 par le capitaine Thomas Sankara, Président du CNR [Unpublished manuscript].

Traore, D. 1985/1986. Le Musée National du Burkina: Approche historique. Unpublished MA dissertation. Université de Ouagadougou.

Traore-Sanogo, M. 1996. La National Cultural Week, Impacts socio-économiques (1983-1994). Unpublished Mémoire de Maîtrise. Université de Ouagadougou.

Unesco. 1981. L'affirmation de l'identité culturelle et la formation de la conscience nationale dans l'Afrique contemporaine. Paris: PUF.

Yameogo, L.A. 1989. Pour une administration culturelle déconcentrée au Burkina Faso. African Cultural Institute, Regional Centre for Cultural Action, Cultural Counsellors Section, Project Dossier, Lomé.

\section{Ministerial orders, reports, minutes and unpublished documents}

Arrêté n`2003-395/MCAT/SG/SP-SNC, portant Règlement Intérieur du Grand Prix National des Arts et des Lettres (GPNAL) de la 12eme édition de la SNC Bobo 2004. Catégorie A et B.

Arrêté n²005-201/MCAT/SG/SP-SNC, portant Règlement Intérieur du Grand Prix National des Arts et des Lettres (GPNAL) de la 13eme édition de la SNC "Bobo 2006". Catégorie B.

Arrêté n ${ }^{\circ 99-0011 / M C C / S G / S P-S N C, ~ p o r t a n t ~ R e ̀ g l e m e n t ~ I n t e ́ r i e u r ~ d u ~ G r a n d ~ P r i x ~ N a t i o n a l ~ d e s ~ A r t s ~ e t ~}$ des Lettres (GPNAL) de la 10eme édition de la SNC "Bobo 2000".

Procès Verbal de délibération du jury de la catégorie B SNC Bobo 2004.

Rapport général du Comité technique de réflexion pour le Séminaire national sur le redimensionnement de la Semaine National de la Culture du 16 au 17 septembre 2004.

Rapport général du séminaire sur la SNC du 5 au 10 avril 1993.

Rapport général du Séminaire sur le redimensionnement de la Semaine Nationale de la Culture du 21 au 22 octobre 2004.

Rapport général sur la SNC Bobo 1994.

Rapport relatif à la Délibération du jury de la catégorie B du GPNAL de la Xe édition de la SNC Bobo 2000.

Résultats GPNAL de 1983 à 1996.

Statistiques sur la participation en arts plastiques de 1983 à 2004. 